Article

\title{
An Environmental Critique: Impact of Socialist Ideology on the Ecological and Cultural Sensitivity of Belgrade's Large-Scale Residential Settlements
}

\author{
Vladan Djokić, Jelena Ristić Trajković * and Verica Krstić \\ Faculty of Architecture, University of Belgrade, 11000 Belgrade, Serbia; vdjokic@arh.bg.ac.rs (V.D.); \\ vericamedjo@gmail.com (V.K.) \\ * Correspondence: arch.jelena.ristic@gmail.com; Tel.: +381-655-999-355 \\ Academic Editor: Tan Yigitcanlar \\ Received: 14 July 2016; Accepted: 31 August 2016; Published: 9 September 2016
}

\begin{abstract}
This paper advocates the stance that sustainable approaches in architecture, although usually associated to contemporary practice, have a very complex relationship with the history of architecture and urbanism. By adopting an interpretative framework, the paper highlights the environmental aspects of the architectural practice of Belgrade's large-scale residential settlements created under the cultural influences of socialist ideology. The socialist system enabled systematic implementation of the principles of the Congrès International d'Architecture Moderne (CIAM) on a large urban scale, in contrast to capitalist countries where these principles were applied on a smaller scale. The paper starts with the premise that these cultural influences, together with the integration of the principles of modernism, caused the rejection and the loss of traditional and ambience values in architecture. Research has shown that these values play a very important role in meeting the needs of ecological and cultural sensitivity in architecture. In its final consequences, the results of research have revealed that, although widely criticized for its break with tradition and the loss of ambience values, residential architecture in Belgrade during the socialist era included significant aspirations of the architectural practice directed at the improvement of aspects of sustainability, and especially aspects of ecological and cultural sensitivity.
\end{abstract}

Keywords: architecture; environment; ecological and cultural sensitivity; sustainability; ambience; tradition; socialist ideology; residential settlements; Belgrade

\section{Introduction}

This paper researches the aspects of ecological and cultural sensitivity of Belgrade's large-scale residential settlements that were built after the Second World War, under the influence of socialist ideology. The paper highlights the significance and necessity of discussing the issues of ambience and tradition in the design process in order to design sustainable, ecologically and culturally sensitive objects and settlements.

In view of the fact that inter-war residential architecture in Belgrade was mostly reduced to family houses, villas and residential buildings with apartments for rent, built as row houses, and also that in the period between the two world wars no residential settlements or larger urban blocks of residential buildings were constructed in Belgrade [1], the chronological frame of research was defined as the period from the Second World War to the 1990s. In this period, under the influence of socialist ideology, a very large number of residential settlements were built in Belgrade. It is important to note that the construction of these settlements started in the modernist era, when the idea of socially and environmentally responsible architecture began to be developed [2,3]. The socialist system provided systematic implementation of the principles of the Congrès International d'Architecture Moderne (CIAM) on a large urban scale, in contrast to capitalist countries where these principles were employed 
on a smaller scale. Designed as large housing areas according to the principles of the Athens Charter [4] and modernism, within the strong ideological context of the socialist system, these settlements were of great interest in terms of Belgrade future development and quality of life [5]. Rather than offering a chronological analysis of the abovementioned aspects of tradition and ambience in selected residential settlements, the paper illustrates key architectural positions regarding the environmental issues of tradition and ambience. The paper hypothesizes that in residential settlements the issues of tradition and ambience play a very important role for the quality of the experience of these settlements and in achieving ecological and cultural sensitivity.

This paper advocates the stance that rational action in further urban development can be planned only if we understand the meaning of the phenomena, processes, conditions and planning strategies of the city throughout history. Although Van der Ryn and Couvan claim that before the 1970s architects did not have an environmental vocabulary, there is a whole set of architectural works related to the position of man in the context of ecology that was created before the emergence of environmentalism in the 20th century [6]. Research and identification of environmental aspects in the architecture of the 20th century are very important. Anker and Farmer emphasize that environmental aspects have a very complex relationship with the history of modern architecture and urbanism [3,7]. Having in mind that the environmental crisis is also a crisis of design, in many ways, it is a consequence of how things are made, buildings are constructed, and landscapes are used [6]. Accordingly, research of the environmental aspects of Belgrade's residential settlements from the socialist era may greatly contribute to understanding and improving these aspects in architectural practice.

The relevance of this research topic reflects the need to improve the environmental aspects of architecture in accordance with the global issues of sustainability, as well as with the changing position of nature in contemporary culture [8,9]. Regarding the concept of sustainability and its widely recognized contested nature, we consider it a holistic response to the environmental crisis that makes much-needed connections between nature, culture, values, power relationships, and technology [6]. Accordingly, this paper studies environmental aspects considering the varying degrees of the power struggle between dominant cultural ideology and architectural positions. Thus, by adopting an interpretative framework, the paper highlights the social production of space, place and the environment $[10,11]$. Furthermore, recent decades have seen a constant emphasis on the importance of environmental knowledge and interpretation within architectural theory in order to create an ecologically and culturally sensitive environment [10]. As Nikezić and Marković state, the need for a holistic approach, and hence the integration of a wide scope of environmental knowledge in architects' education, becomes vital and urgent, and the architect is perceived as one of the key agents involved in the process of creating a sustainable environment [12].

We consider sensitivity in the architecture of residential settlements as an ability to accommodate diverse ecological and cultural values, and different ways of living. Research indicates that ecologically and culturally insensitive housing, and building in general, with the accompanying loss of traditional and ambience values can lead to various problems regarding a sustainable relationship between residents and their environment. This dynamic relationship constitutes not only the physical aspect of space, but also its function, behavioral aspects, temporality, and its sensory aspects. Human presence is central to the environment. Accordingly, Hawkes states that environmental experience is of crucial importance to architecture, though the formal and technological aspects of architectural research tend to ignore it [13]. It is therefore important to emphasize that in this paper the environment is studied not as a technological and scientific, but primarily as a social and cultural topic. It acknowledges the wholeness of environment, and also the inseparability of nature and culture as its integral parts. This implies a social and cultural approach to nature, as opposed to regarding nature as a physical entity, or merely people's surroundings [14].

Since definitions of the concept of ambience are based on the phenomenological aspects of the constitution of architectural ambiences, the role of the environmental experience is very important for the quality of ambience. The concept of ambience is largely tied to the positive connotations of a pleasant experience of space [15]. One of the basic characteristics of ambience is a sense of belonging 
and dedication to the senses [16]. Pallasmaa considers ambience as sensory characteristics emitted by a space. The immediate form of physical perception is always related to the emotional sensitivity of the observer [17]. Ambience is a mental backdrop, experiential quality or characteristic, stretched between the subject and the object observed. Thus, ambience is not a passive layer of the everyday life, but essentially its integral part [18].

Besides issues relating to ambience, this paper also explores the consequences of the rejection and the loss of traditional values in architecture with regard to ecological and cultural sensitivity. Large-scale cultural influences, primarily of socialist ideology, but also the integration of the principles of modernism in architecture led to the rejection of the traditional urban block and the cultural values of local context, the neglect of ecological characteristics of places and vernacular knowledge, loss of human scale, identity, unification, etc.

The results of the study reveal that, although widely criticized for their lack of tradition and the loss of ambience values, socialist residential settlements still showed a specific attitude towards sustainable issues and specific environmental values.

\section{Methodological Approach}

The research includes a historical-interpretative approach [19] in the domain of architectural and urban studies, enabling an in-depth qualitative exploration of the environmental aspects of tradition and ambience within their complex historical contexts, with the intention of explaining these aspects as a narrative and in a comprehensive manner.

The initial phase of research included an analysis that was based upon the studies of completed residential settlements and an extensive literature review of books, articles, and reports covering topics related to socialist ideology, sustainability, housing, ecological and cultural sensitivity, ambience and tradition. Among the primary sources, the most important are those that represent the initial planning and architectural documentation relating to Belgrade's residential settlements, reports of expert panels and published articles. Secondary sources include materials offering theoretical insight into the development of environmental and sustainable approaches in architecture, articles that problematize the cultural and social history of Belgrade and Yugoslavia and texts pertaining to the history and theory of architecture in Belgrade and Yugoslavia.

In the second phase, the influence of socialist ideology on the ecological and cultural sensitivity of Belgrade's residential settlements was analyzed. First, it was necessary to theoretically introduce the broader social and cultural context of socialism and the ideology of residential construction. Then specific aspects and principles of the dominant architectural styles (modernism and postmodernism), which served as an instigator of socialist ideology with the aim of creating a new society and a new system of values, were explained. Finally, the influence of specific phenomena of socialist ideology on traditional and ambience values in the residential settlements that are the subject of this research was determined and described.

The case studies of residential settlements of the research are shown in Table 1:

Table 1. Residential settlements of Belgrade, 1959-1989, selected as case studies.

\begin{tabular}{|c|c|c|c|c|}
\hline & Description & Architects & Origin of Design & Realization \\
\hline (1) & Blocks 1 and 2 in New Belgrade & $\begin{array}{l}\text { Leonid Lenarčič, Milutin Glavički, } \\
\text { Milosav Mitić and Dušan Milenković }\end{array}$ & $\begin{array}{l}\text { competition, } \\
\text { Belgrade, 1958-1959 }\end{array}$ & 1959-1963 \\
\hline (2) & Block 21 in New Belgrade & $\begin{array}{l}\text { Mihailo Čanak, Leonid Lenarčić, } \\
\text { Milosav Mitić and Ivan Petrović }\end{array}$ & $\begin{array}{l}\text { competition, } \\
\text { Belgrade, 1958-1959 }\end{array}$ & 1962-1966 \\
\hline (3) & $\begin{array}{l}\text { Residential settlement } \\
\text { "Julino brdo" }\end{array}$ & $\begin{array}{l}\text { Milan Lojanica, Borivoje Jovanović } \\
\text { and Predrag Cagić }\end{array}$ & $\begin{array}{l}\text { competition, } \\
\text { Belgrade, } 1966\end{array}$ & 1967-1970 \\
\hline (4) & Block 19a in New Belgrade & $\begin{array}{l}\text { Milan Lojanica, Predrag Cagić, } \\
\text { Borivoje Jovanović, Radisav Marić } \\
\text { and Radmila Lojanica }\end{array}$ & $\begin{array}{l}\text { competition, } \\
\text { Belgrade, } 1975\end{array}$ & 1977-1982 \\
\hline (5) & $\begin{array}{l}\text { Residential settlement "Cerak } \\
\text { vinogradi" (Cerak } 1 \text { and Cerak 2) }\end{array}$ & $\begin{array}{l}\text { Darko Marušić, Milenija Marušić and } \\
\text { Nedeljko Borovnica }\end{array}$ & $\begin{array}{l}\text { competition, } \\
\text { Belgrade, } 1977\end{array}$ & 1979-1989 \\
\hline
\end{tabular}


The final phase of research also included a comparative analysis performed at two levels: as a mutual comparison of architectural design positions and as a comparison with traditional and ambience values. The synthesis and interpretation of results included formulation of new research questions and conclusions in relation to the level of ecological and cultural sensitivity achieved in the analyzed case studies.

The selection of residential settlements as case studies was guided by taking into account the complex issue of sustainability in residential spaces. In addition, residential settlements allow study of the mentioned aspects at different spatial levels, from the level of the object to that of the neighborhood or block, particularly in relation to major cultural influences, both foreign and domestic, and their impact on ecological and cultural sensitivity. In addition, such a research field includes study of the local context as an important aspect of sustainability.

\section{Background: The Importance of Sustainability Issues under the Influence of Socialist Ideology}

\subsection{Social and Cultural Contexts}

Regarding the construction of residential settlements, the research period includes the time of the greatest technological and social changes in the territory of Belgrade. The change of the political system and of the dominant social goals and the redirection of state production from agriculture to industry after the Second World War brought about radical transformations of urban life. Large migrations to the major administrative centers of working people employed in the state sector led to accelerated population growth in the cities, Belgrade in particular, and a large deficit of housing units. These problems caused a transition to a new state housing policy and the introduction of a new concept of solving housing issues using mass construction [20]. Under the national modernization strategy, new technologies of prefabricated construction developed, which the majority of these residential settlements realized. Jovanović Nenadovic writes that the creation of a new-socialist-state in the post-war atmosphere of collectivism, supported by a desire for a brighter future and a real need for new housing units, brought about the adoption of the ideas of modernism as a mandatory component of social reform a means of expression of the moment: Modernist principles-idealism and faith in the creation of a new world-were accepted as the main instigator of social reforms [21]. Under such terms, with the obvious need for constructing large-scale residential settlements and in the conditions of equality of standard, New Belgrade and peripheral city locations outside the boundaries of traditional urban areas represented highly convenient areas for construction.

Such residential ideology is first of all a consequence of the deterministic position of designing "a complicated scheme for organizing a new society, even a scheme of man's own life" that was at the top of the list of priorities of the socialist state [22]. Residential systems were designed in accordance with the ideological principles of socialism. One of the basic requirements was collectivism, as a prerequisite for social and political identity, along with social justice, also a key phenomenon in this period.

\subsection{Socialist Ideology and the Concept of Sustainability}

In the 1970s, in accordance with the then current development of the idea of sustainability worldwide, many initiatives were launched in Yugoslavia with the aim of preserving and protecting the environment. Theses about the affirmative acceptance of the shaping of the environment gained importance, both in architectural practice as well as at conferences and in literature [22].

It is very important to emphasize that the constitution of the Socialist Federal Republic of Yugoslavia, adopted in 1974, included a regulation stating that "it is the duty of the socialist society to provide conditions for the preservation and development of natural and other values of the environment that are of interest to the healthy, safe and efficient life and work both of the present and of the future generation" [23]. Keeping in mind that the Brundtland Report, which defines sustainable growth as growth that satisfies the needs of the present moment without compromising the potential 
of future generations to satisfy their own needs [24], was published 13 years later, in 1987, we may speak of the progressive nature of ecological attitudes of the Yugoslav socialist state.

Using the constitutional concept of communities of interest, the socialist society aimed to regulate certain socio-economic relations using new forms and mechanisms. Thus, in the 1970s, initiatives were also launched to educate self-governing communities of interest in environmental protection with the goal to realize one of the basic human rights-the right to live and work in a healthy environment [25].

In the academic community, the significance of ecology in design disciplines was stressed, as well as the fact that the process of directly involving ecology in planning and design was progressing very slowly due to insufficient familiarity with the problem, academic skepticism towards the environmental community and the insecurity of design disciplines about "what an ecologist may or may not do" [22]. With the concept of ecology, the concept of environment became widely popular in the expert literature of the 1970s. Thus, in a 1973 issue of the journal Čovjek i prostor ("Man and Space"), we find interpretations of all three concepts of environment, ecology and habitat [26]. In addition, landscape and region became increasingly important topics in relation to ecology, i.e., the ecological characteristics and aspects of landscape protection in spatial planning, urbanism and architecture. Emphasis was placed on the need to coordinate economic and social growth with the natural, i.e., biological potentials of a specific region [27].

In his text entitled "Man's environment at the time of accelerated urbanization in Yugoslavia", on the occasion of the convention of urbanists of Yugoslavia held in 1971 under the same title, Rajić classifies Yugoslavia among countries with a just awakened interest in man's environment. Emphasis is placed on awareness of the thoroughly compromised natural environment, of the "total and drastic extent" of the consequences of polluting man's environment [28]. The abovementioned journal Čovjek i prostor published another article in 1973: Keller writes about the relationship between socialism and ecology. He stresses that to many it may seem incompatible to discuss the relations of socialism as a model of socio-political state and ecology, while to others this may sound as a dogmatic phrase. However, after comparing the characteristics of socialist and capitalist systems, he concludes that due to its determinations capitalism is "in essence incapable of solving any ecological problem. Therefore, he continues", precisely at the level of the environment, the capital opportunity of socialism can be seen:

If efforts are concentrated on creating such an environment that would be a decent place for a man to live and work, that would fully display the desires, potentials and knowledge of man, socialism may find the strength to overcome these problems. This understandably implies that the creation of a new system of socialist cultural and ethical values should also incorporate new attitudes towards our surroundings [29].

It was believed that the protection of the environment is an integral part of the socialist self-governmental restructuring of society and thus a need was expressed to develop ecological awareness through systematically educating youths [30]. In addition, the battle for the environment was highlighted as the converging point of the biggest social problems: "The environment is, finally, the image of a society permeated by its values, so it necessarily reflects its general state, its material culture, its readiness to evolve" [31].

In 1973, Yugoslavia hosted a conference on the occasion of the "World Urbanism and Environment Day" [32]. As Petrinović writes, the initiative of international organizations to appoint the Federation of Urbanists of Yugoslavia as the organizer of the event represented a "significant reward to Yugoslav people who gave their constructive contribution to solving problems related to urbanism, spatial planning and environmental protection, whereby gaining significant international and national recognition, to which this latest reward is added" [32].

Regardless of the previous decisions and initiatives in the field of protection and preservation of the natural and built environment, however, awareness began to develop in the 1980s about new problems and the fact that in reality many aspects of environmental protection did not function properly. 
It was stressed that with regard to raising awareness about environmental protection, the socialist society had made great advancements, but that regarding practice there were still no significant results, according to the opinion of the academic community of the time [33].

In the 1970s and 1980s, a large number of conferences were held on topics of environmental protection and promoting ecology in human settlements. In addition, a significant number of expert and scientific papers appeared on the subject. It is important to note that in light of the development of consciousness about climate change, particularly the topic of solar energy and its role in planning and design grew increasingly popular [34-36].

The issues surrounding sociological and psychological aspects were kept up-to-date by a constant exchange of experiences with colleagues from abroad. Thus, in March 1978, the Students' Cultural Center, the Faculty of Architecture in Belgrade and the Federation of Societies of Architects of the Federal Republic of Serbia organized an exhibition on Austrian architecture and urbanism and a meeting with eminent experts, professors at the Faculty of Architecture in Vienna. On this occasion, several lectures were held related to experiences in Austria and to scientific research in other countries. In the conclusion and summary of the events provided by the journal Urbanizam Beograda ("Urbanism of Belgrade"), a paper was published entitled "Emotional and psychological aspects of dwelling in new settlements". As one of the key terms related to this topic, the concept of "the quality of residential environment" stood out: "quality of residential environment-emerged as a term only recently, with a broader and more complex meaning that also includes, besides satisfying the basic needs, aspects of emotional and psychological experience of the residents" [37]. In this context, the "lack of emotional values in the city" [37] was suggested as one of the main problems, and large-scale design is listed as one of its basic causes.

\subsection{Architectural Positions - Influences and Principles of Dominant Architectural Styles in Socialism}

Modernism and postmodernism were the dominant architectural styles in socialist Yugoslavia, and Belgrade in particular. These architectural styles were in the service of the goals of socialist ideology and the formation of a "new" socialist culture. The mentioned aspects of ecological and cultural sensitivity were directly affected by the principles of these architectural styles, especially the attitude towards ambience and the traditional values in architecture. This section defines the principles of the aforementioned architectural styles which are relevant to this study, in order to establish and interpret their specific influences on the issues of tradition and ambience in the next phase of research.

Considering the relationship of modernism and socialist ideology, it is important to note that, as Groat states, the most influential architects (and artists) of the modernist era saw themselves as the avant-garde leaders of a new mass culture; they sought both to establish a new society (based on advancements in science and technology) and to generate a process which would presumably eliminate both the physical and social ills of the past [38]. As described in the previous section, this approach completely corresponded to the housing policy in Yugoslavia in the period analyzed.

The concept of sustainability may be connected with the ideas of modernism that regarded the sustainable link between nature and the city. This significance of nature in modernism was reflected in the desire to provide a healthy environment including sun, fresh air and greenery. However, modernism denied the specificities of the local context, i.e., its landscape, climate, topography, biosphere, weather conditions, etc. [8]. Therefore, nature had value only if universal, and was thus regarded when designing objects. Besides, as Banham suggests, the intention of modernism was to free the world of the inadequacies of vernacular architecture [39]. Accordingly, the ideology of the modernist movement in the newly designed Belgrade settlements was promoted through the vision of a new, clean and healthy city, as well as the application of novel, contemporary technologies. Such an approach is in accordance with the hygienic policies introduced by modernism and that were also dominant in the first realizations of New Belgrade's settlements. Modernism, however, also recognized the "logic of dominance" over nature propagated by Le Corbusier, primarily using human order, geometry and rules [40]. This type of dominance became especially recognizable in the 
previously deserted field of Bežanija in Belgrade, where the accelerated metabolic transformation of nature is most visible, both in the physical form and in its socio-ecological consequences.

The basic idea was that the principles of modernism in architecture were based on the assumption that architecture is an art, but also that it is at the same time an environmental practice. Modernist architecture was certainly focused on design and the idea of designing a habitat of higher quality for all people. In this sense, concern was clearly expressed about the alienation of people from nature, long daily trips to the workplace, pollution, and unjust social stratification, lack of daylight and ventilation in most residential spaces and, generally, overpopulation of the cities. However, although all these aspects are of significance for the modernist principles of environmental design, the modernist movement was certainly largely preoccupied with architecture as art, which resulted in numerous problems in the use of settlements that were directly related to the issues of ambience and tradition. It was believed that, as the result of such an approach, "places deprived of specificity-or even annulled" were created [11]. For example, as a result of such a universal view of nature, but also of the resident, settlements soon after they were built these settlements were characterized as "monotonous and inhumane" [41]. At the first meeting of the Architects of the Federal Republic of Yugoslavia in Dubrovnik, 23-25 November 1950, Ribnikar talked about how social realism had materialized into many ugly, gloomy and heavy buildings [41]. Such views were in accordance with the current global criticism of settlements built in the modernist style. Therefore, the relationship between sustainability and modernism is somewhat paradoxical in its nature.

Criticism of modern architecture, and the fact that the professional engagement of architects and others involved in the design process was often far from what had been expected and planned, contributed to an awareness of the necessity of the improvement of environmental issues in architectural practice in the socialist context.

On the other hand, within the architectural paradigm in architecture, thinking about form independently of the traditional limited concept of function, inherited from the first generation of modern architects, was a characteristic of the postmodern generation of architects. Focus was also largely placed on the characteristics of local context, identity, and a reaffirmation of regional architecture, as well as a break with the Congrès International d'Architecture Moderne (CIAM) and the Athens Charter. Accordingly, a desire was expressed to design a richer environment than the one advocated by the Athens Charter, although the environments designed by this generation of architects have also been described by residents as sterile. These positions directly influenced the reaffirmation of traditional and ambience values in architecture.

Regarding the scientific epistemology and the topic of ambience in architecture, postmodern thought essentially reflects a crisis of confidence in science and technology [42]. Postmodernist aims to connect ecological action and perception became increasingly important [43]. In contrast to modernism, we cannot identify its precise design principles, but we can recognize the influence of different theories on architectural design. Phenomenology was certainly among the most dominant theoretical influences in this period [38], and offered a theoretical basis for promoting the issues of experience and sensitivity, especially ambience issues in architecture.

\section{Ecological and Cultural Sensitivity}

\subsection{Abandonment of Traditional Values}

As mentioned above, on a philosophical level, modern thought has been characterized as a cultural template of liberation from traditional ways of thinking, believing, and acting-and later from tradition itself [38]. Criticism of the architecture of residential settlements created in Belgrade under the influence of modernism is directed primarily at the abandonment of the rich vocabulary of a traditional city.

Under the conditions of equal standards, a need for building a large number of residential settlements outside the boundaries of traditional urban areas greatly influenced the design and conception of residential objects and blocks [20]. Socialist standards brought about a specific way of 
"producing" universal residential environments. As a result, residential objects were designed under a concept of equality of urbanistic disposition and visual esthetics (Figure 1).
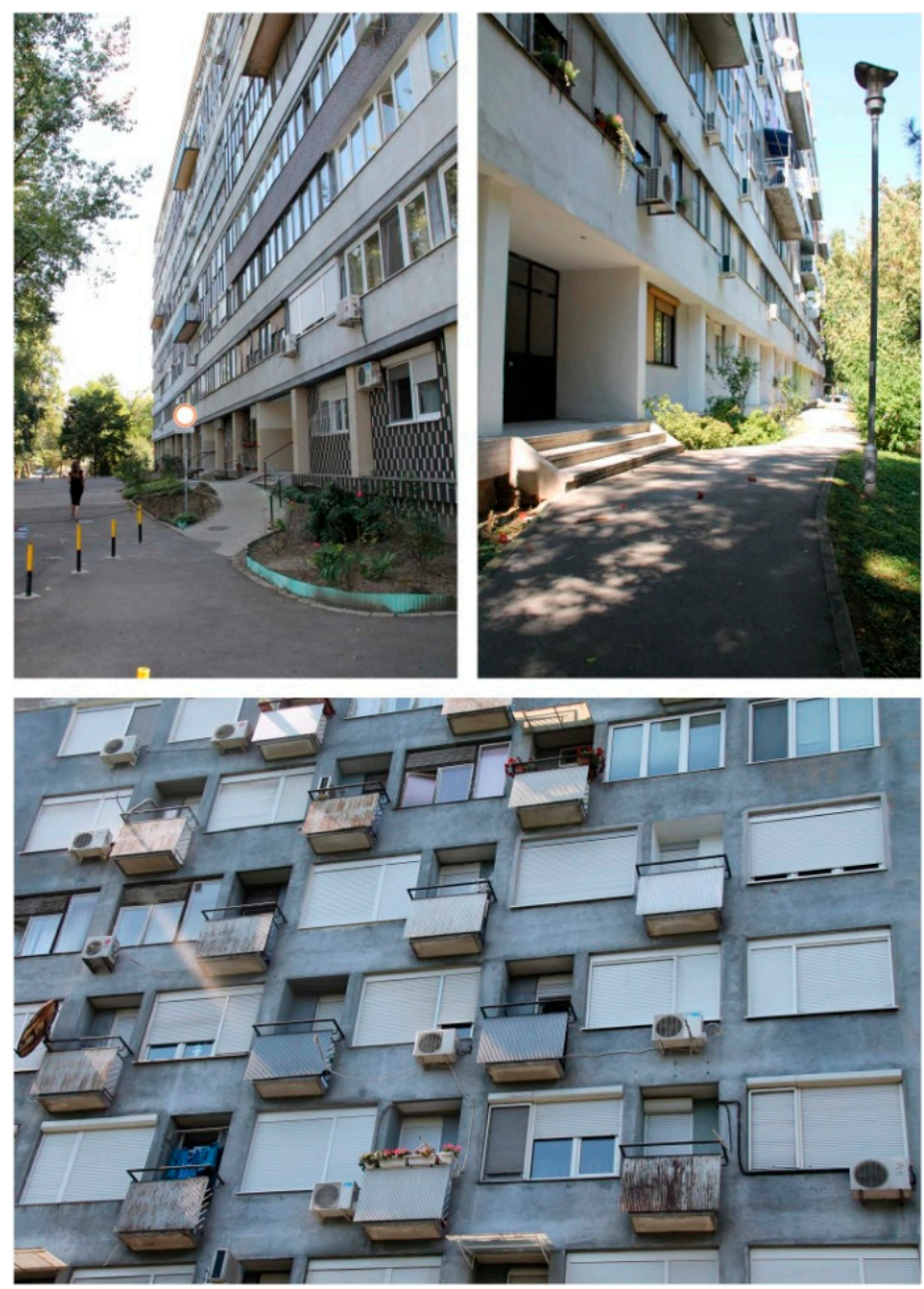

Figure 1. Residential settlements Blocks 1 and 2 in New Belgrade $@$ C Verica Krstić.

Although conceived under a concept of open blocks surrounded by greenery with the aim to improve the quality of life, the residential settlements built according to modernist ideas provoked numerous criticisms as early as in the 1960s, primarily directed at urban zoning, which inevitably resulted in the breakdown of integrated and polyfunctional communities into monofunctional zones [5]. Similar criticism was also present in the global architectural theory and practice of the time. Harvey reminds us of the work of Leon Krier, who criticized modernist urbanization, claiming that monofunctional zoning is "anti-ecological" because it leads to unnecessary consumption of time, energy and land. At the opposing end, Krier describes a "good town" (ecological by nature) in which the "totality of urban functions" are enabled by "compatible and enjoyable walking distances" [44].

Negative residents' experiences with the use of modernist settlements and increasingly sharp criticism of the rejection of traditional urban blocks, loss of human scale, appearance of alienation and lack of interaction, led architects to adopt the general view that these residential spaces should be in serve everyday life rather than representation. This was confirmed in numerous documents and articles, among which the most significant is a document presenting the final reports and summary of the conference "Future of Residential Settlements (Planning, Programming, Urbanistic Design, Realization, Use)" held in 1977 at the Center for Urban Planning Development in Belgrade [45,46]. This meeting is of great importance because its conclusions represent the general attitude of the expert 
community towards the hot topics and problems related to residential architecture. Architects from the entire former Yugoslavia took part in this conference, among them the architects of the most important residential creations, together with researchers, sociologists, psychologists, etc. Insight into the final reports confirms a developed awareness of the significance of reaffirming tradition in the architectural design of residential settlements. Analysis of these documents leads to a conclusion that architects in this period became aware of the importance of traditional urban forms in designing "settlements according to human scale", and with cultural sensitivity towards conditions of the local context. The report of Working Group D entitled "How to Begin Life in a New Settlement-the Problems of Identification and Social Integration" stresses the need for traditional urban forms, such as street, square, fountain, pillar or any other thing of similar and internal character [46].

Furthermore, the re-examination of spaces and objects of human scale became an important topic in this period. An excerpt from the abovementioned report of Working Group D that speaks of the dimensions of residential space in "human" terms: "There is also a clear need to operationalize what we define as human-scale spaces and objects. There have been some witty examples, like using the reach of the human voice, or the distance to which a mother's eye can see her child etc. as measures" [46].

An example of the gap between modernist principles and residents' perceptions is certainly the role of greenery located around the residential blocks. The modernist desire to create the largest possible areas of greenery between the objects created huge empty spaces between the objects and practically decomposed the traditional image of a city. Such an approach resulted in the residents' dissatisfaction with the quality of achieved ambience and their inability to identify with the space. Architectural theorist Perović believes that just as the objects and their spatial disposition were monotonous, so the available green spaces in the settlements built in the spirit of the Athens Charter lacked identity, unlike traditional cities where each park and square are authentic and do not allow generalization [47]. Case studies from the modernist period (Blocks 1 and 2, and Block 21) undoubtedly confirm these views. In Figure 2, showing an aerial view of Blocks 1 and 2, we may see that the principles of the Athens Charter and functionalism were followed to the letter, with the open green area several times bigger than the area covered by objects.

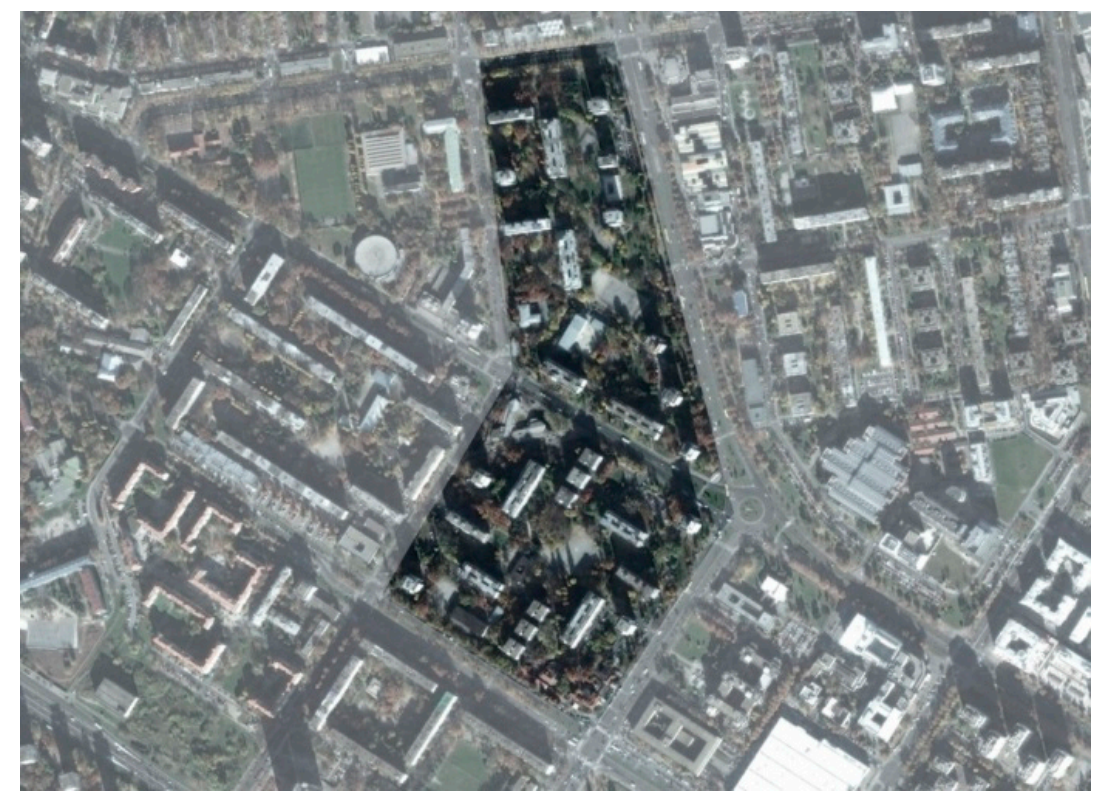

Figure 2. Aerial view of residential settlements Blocks 1 and 2 in New Belgrade [48].

In addition, dimensions of the blocks were several times greater than those of an average traditional urban block in Belgrade's city center. The size of an average New Belgrade block is around $400 \times 400 \mathrm{~m}$, i.e., some $1.5 \mathrm{ha}$, which is around 15 times greater than the average surface of 
a traditional urban block. This great difference in scale between the traditional urban settlements built before the Second World War and after is illustrated in Figure 3.

A

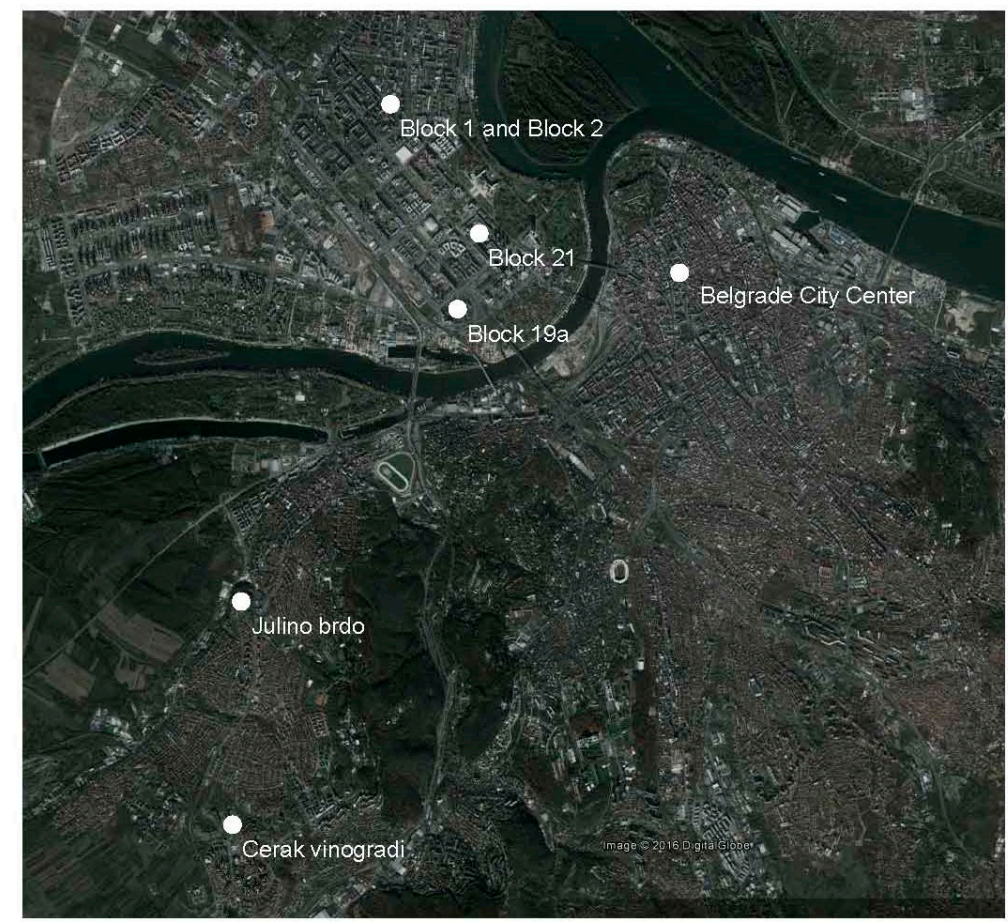

B
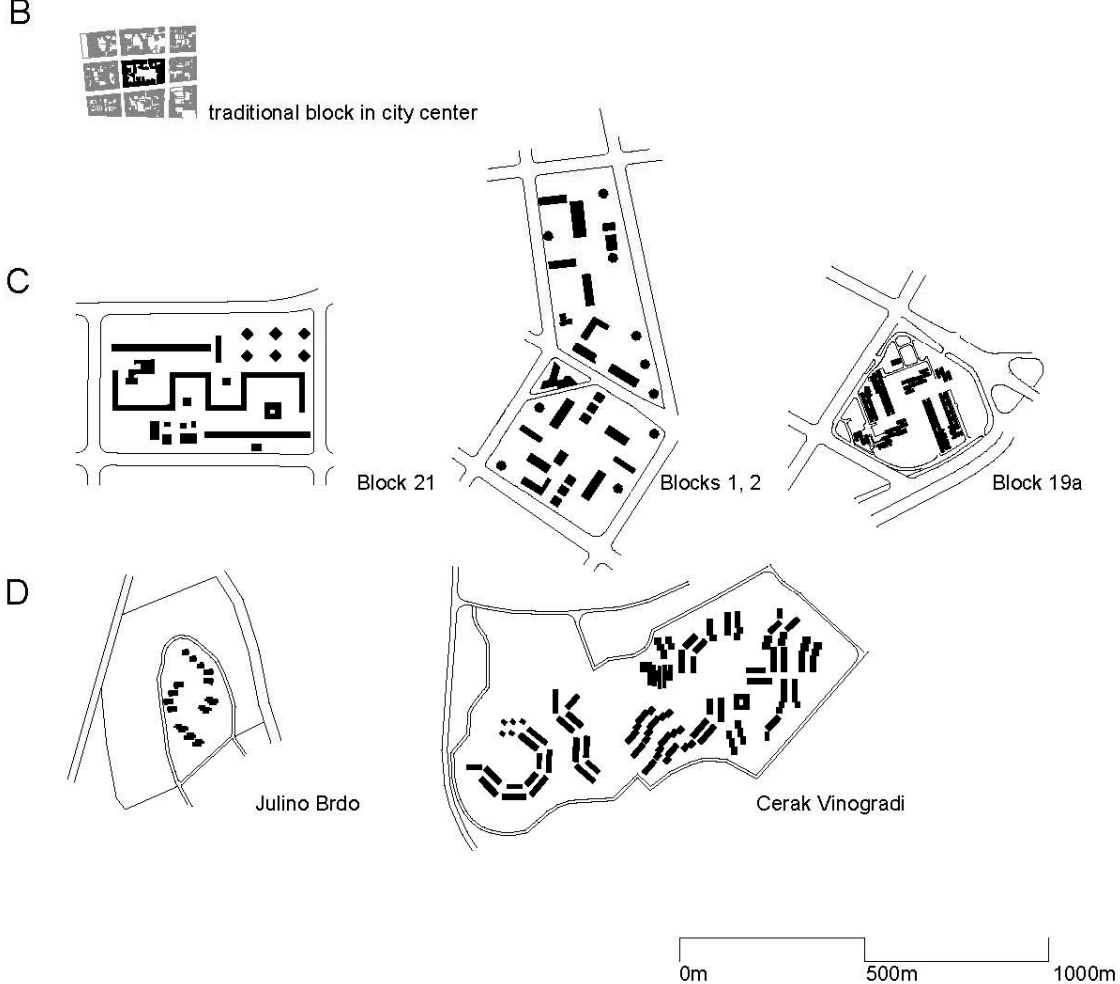

Figure 3. Comparative overview over the scale of the residential settlements: (a) position of analyzed residential settlements on the map of Belgrade [49]; (b) Belgrade's city center-traditional residential settlements built before the Second World War; (c) residential settlements built in the modernist period; and (d) residential settlements built in the postmodernist period. 
The purpose of all forms of vernacular architecture is to meet specific needs, accommodating the values, economies and ways of life of the cultures that produce them. Accordingly, residential settlements built in the first decades of socialist ideology were completely insensitive to the ecological and cultural contexts of Belgrade.

The 1970s brought with them a change of goals and priorities in socialist ideology. Although still overshadowed by politics, cultural representation and the unstoppable surge of nationalism became increasingly popular. According to Ignjatović, in this period, a specific phenomenon within the architectural paradigm of postmodernism was the revalorization of vernacular knowledge, which implied a series of strategic roles corresponding with the renewed interest in historical and local heritage. Within Serbian architectural culture, these roles were stressed by constant emphasis on contextual reference and signification of regional identity [50]. Unlike modernism that advocated revoking vernacular influences in architecture, postmodernism stressed the importance of harmonizing objects with the environment, its ecological and cultural characteristics. Thus, reaffirmation of regional architecture was evident in this period.

A consequence of the increased interest in the vernacular was the resignification of residential settlements by redefining the "universal modernist syntax of socialist aestheticism" [50]. Emphasis was placed not only on the use of traditional elements in the sense of visual identity, but also the use of local materials. This trend was followed by an increasing interest in old rural houses from various regions of Serbia. The traditional elements of these houses were used as antitheses to the universal vocabulary of the modernists, easily recognized in the realization of residential objects in Block 19a. Figure 4 reveals highly specific interpretations of traditional forms, such as pitched roofs on high-floored multifamily residential objects.

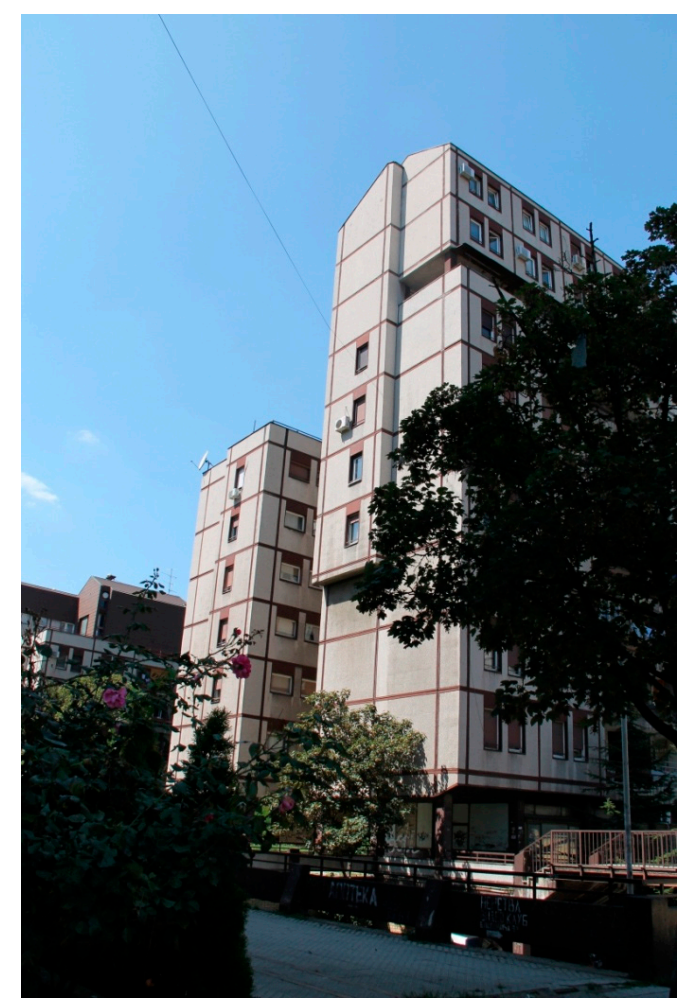

Figure 4. Residential settlement Block 19a in New Belgrade ( Verica Krstić.

According to Ignjatović, in the analyzed period, the context and the contextual, along with the importance of respecting the specific characteristics of a place, its "genius loci", became dominant topics in the referent discourse about the architecture of Belgrade and Serbia, enforcing the position of 
a model of inverted traditions at the throne of greatest cultural values [50]. Reaffirmation of the "spirit of a place" and phenomenological theories as prerequisites for designing quality environments led to increasing criticism of architects for their lack of knowledge about the context and culture in which something was being built [45].

From 1979 to 1984, Perović expressed his criticism of modern urbanism and the possibility of New Belgrade's urban revival in his two research studies on development of a traditional neighborhood. Perović pointed out that the objectives once set for the development of central activities in New Belgrade should not remain permanent, but should depend on the functioning of social, economic and cultural development, so that the urban structure of New Belgrade should not be the final outcome, but only one part in a continuous and sustainable planning process [47].

The analyzed aspects of the influence of socialist ideology on traditional values have been summed in Figure 5 that shows a comparative overview of the relations of relevant spatial levels, socio-behavioral-cultural phenomena and traditional values.

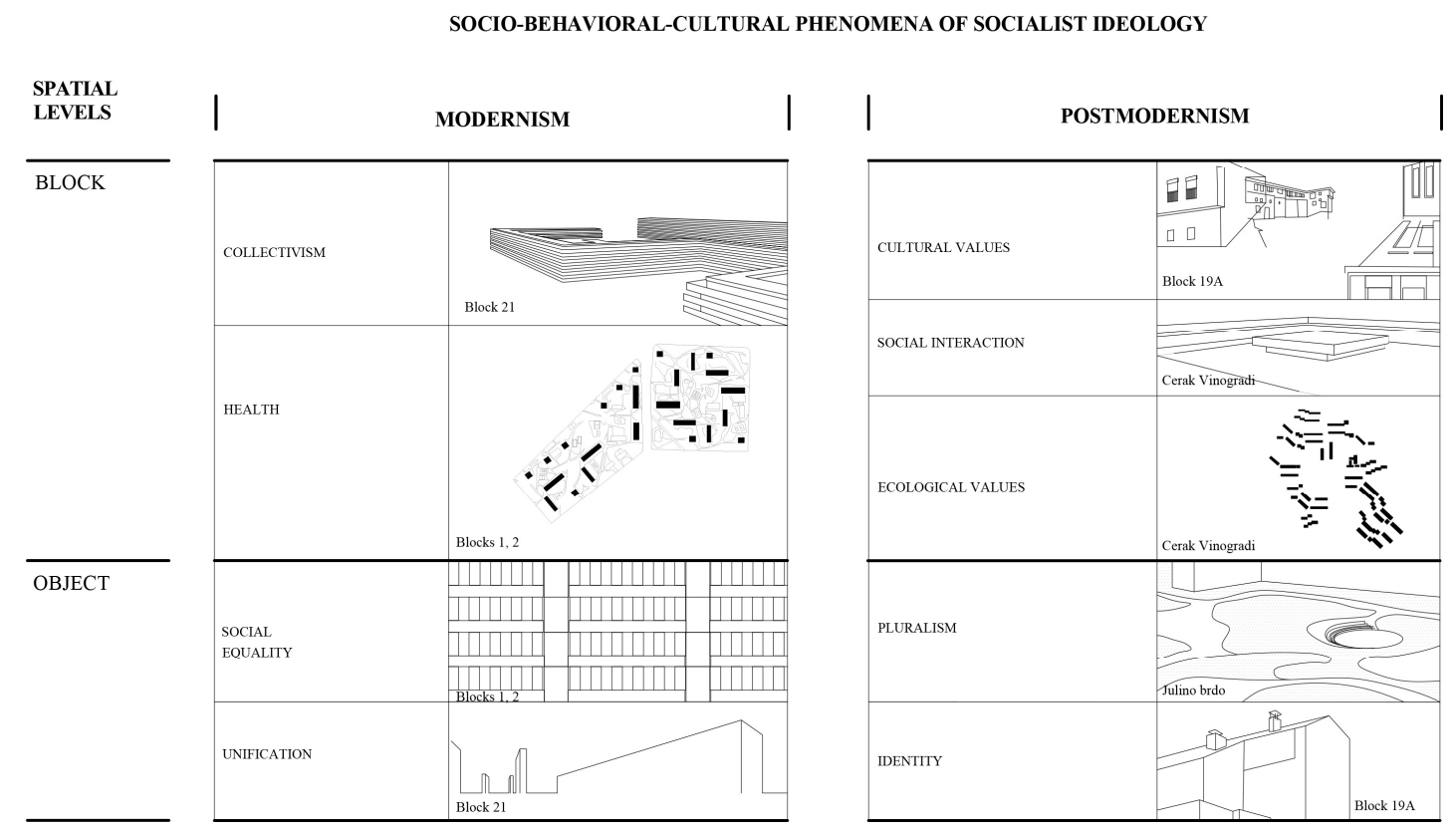

Figure 5. Comparative overview of the relations between relevant spatial levels, socio-behavioralcultural phenomena of socialism and traditional values [22].

Importance of traditional cultural values was constantly highlighted as a major factor in the conception of architectural objects. From the contemporary position of sustainability, it is clear that this attitude contributed significantly to improving the cultural sensitivity of analyzed residential settlements.

\subsection{Loss of Ambience Values}

We speak of atmosphere as something that is commonplace and self-evident for residents and that is constantly produced by locals throughout their lives [51]. The atmosphere of a residential settlement is considered as something characteristic for, i.e., specific, to a context, which makes it authentic and therefore cannot be communicated using general concepts and ideas. Analyzed from this aspect, the conceptual preferences of functionalist urban planning after realization produced "an utterly simplified and schematized image of the city" [47]. Settlements built according to these principles were "more like realized diagrams than cities created to meet all the various life's needs, without the picturesque qualities of traditional cities based on intimacy and the diversity of ambience, diversity of experience, i.e., sequential visual contrast" [47]. In the 1960s and 1970s, the limitations 
of the modernists' model of man and their views on human behavior became known, explicitly or implicitly. Greater diversity and variety of approaches were requested from architecture so as to answer the truly great diversity and variety of human needs and personalities. Accordingly, the topic of ambience became increasingly important.

Modern architecture was mainly criticized for its focus on form and stereometric patterns that inevitably leads to a lack of interaction between the resident and the environment, both built and natural, and completely neglects spatial relations in architectural design. The significance of environmental experience also became a subject of debate, particularly with regard to the issues of resident's identification, sense of belonging, and alienation. The influence of modernism on ecological and cultural sensitivity was also criticized regarding examples of inhumane residential environments created as a result of the architects' focus on designing architectural masterpieces. In view of the complex nature of the environment, in a 1973 article called "Environment is a process. Thematic options for a new practice", Dakić and Kritovac criticize superficial initiatives for humanizing the environment and draw attention to the popular tendency of achieving environment humanization "by merely collecting a sufficient number of authentic high-quality objects, which certainly does not lead to a wholesome observation of the environment" [52]. From an aspect of object perception, in modernism, major criticism was directed at the focus of architects on the visual determinants of space and the passive experience of an object by the resident as a work of art. It was believed that reasons for such a standpoint could be traced to the methodology of architectural design, i.e., that in the design process, due to the grandiose dimensions of these residential settlements, architects compared the perception of objects with the perception of the architectural design models, and not concrete works of architecture, which made imagining the real dimensions and real situations an almost impossible task. In addition, a fragmented system offering no sense of belonging to the city or one of its parts was seen as a result of separating functions and urban zoning according to the rules of the Athens Charter. Such architectural practice denied environmental complexity and an environment's inseparability of its geographical and social ambience [53]. Architectural critics relied on the warning issued by Lynch that cities are too often regarded as collections of smaller environments, but that this view is as accurate as the one that holds that a beautiful building is composed of a series of beautiful rooms. Contrary, each physical entity is open to the influence of not only the quality of its parts but of the entirety of its organization and solutions [52].

Case studies of the residential settlements Block 1 and 2 clearly show the mentioned limitations of modernist principles. These blocks were experienced as monotonous compositions of identical objects, repeated many times within the green zones of the open block (Figures 1 and 2). Green zones were designed as autonomous from the objects, according to standardizes matrices, without acknowledging the local characteristics of context. Such an approach resulted in problems regarding the relations of residents and the open green zones, i.e., the inability of residents to identify with these spaces. Analyses show that the mentioned limitations and the autonomy of objects in relation to the open spaces of the block are also features of the residential settlement Block 21 (Figure 6).

In his article "Thoughts on the topic of ambience", Dobrović offers his position on the role of well-designed ambience in relation to man: "For 'thoroughbred architects', it is a humanized environment designed above the usual level of expertise or bourgeois taste" [54]. Based on the characteristics and stratification of ambiences in the old town centers, Dobrovic highlights the importance of ambience and the role of architects in planning new settlements: "Ambience is an even greater thing as a new creation of the present, where one creative act builds entire cities" [54]. In addition, along with the architect's role, Dobrović stresses the role of human as a mediator in the experience of ambience, and the fact that different experiences of the environment depend on local context, culture, etc. [54], which also directly points to the inseparability of geographical and social ambience. Dobrović's observations reveal that even in the cultural context of Yugoslavia's modernism we may discern the origins of a developing awareness of the shortcomings of constructed settlements and the dominant ideological limitations of socialism, as well as an obvious need to change the paradigm in order to promote ambience and traditional values in settlements. 


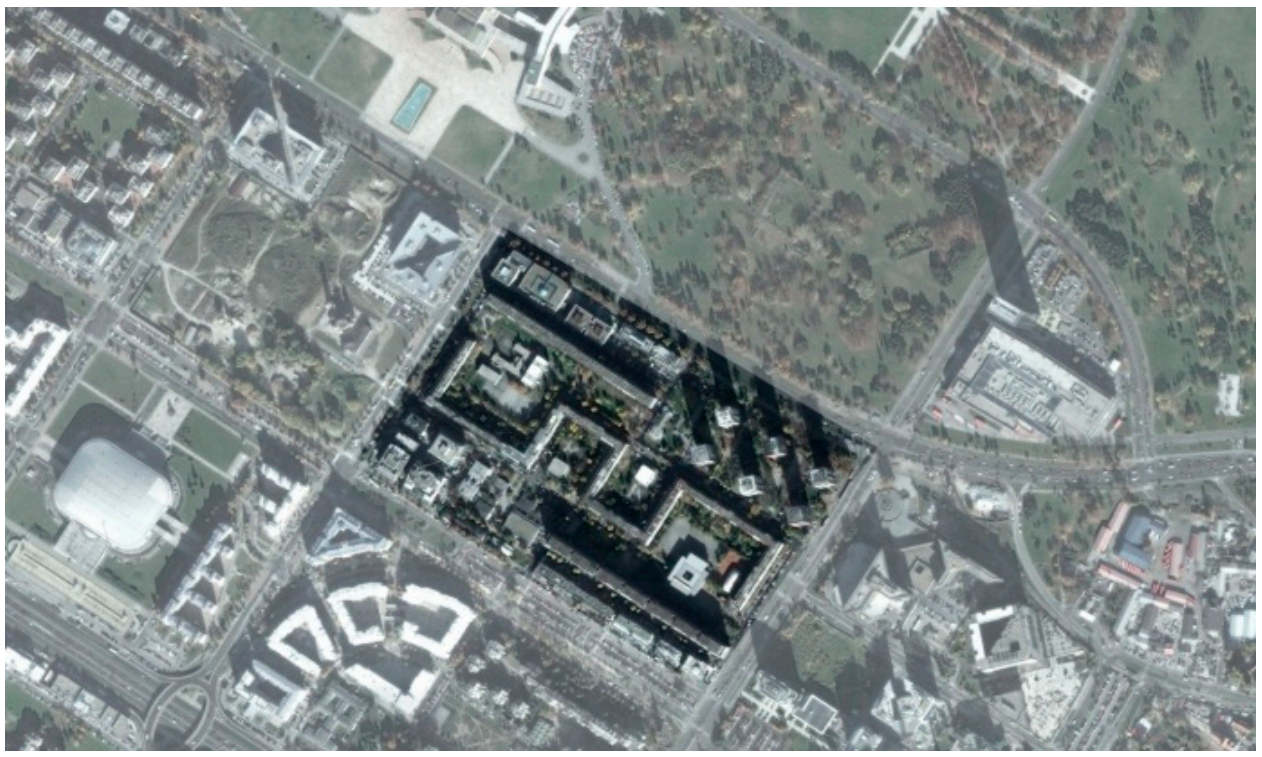

Figure 6. Aerial view of residential settlement Block 21 in New Belgrade [55].

In this period, the hypothesis about the inseparability of geographical and social ambiences and their impact on humans was very important. From the perspective of contemporary theories on sustainability, this hypothesis may be characterized as very progressive, as it advocated not only the establishment of ecological and cultural sensitivity to a specific context, but also the synergy of ecological and cultural aspects of sustainability. At the same time, it confirms today's assumption that nature and culture are inseparable, that is, that an environment is always complex and indivisible:

The origins of creative spatial work are related to natural conditions. Architecture and urban planning were originally an affirmation of the existence of a specific geographical place, which is structured into a geographical ambience by the reciprocity of the subject's presence. The inseparable nature of geographical and social ambience (the so-called natural and artificial environments) in their significance for man implies the specialty and uniqueness of each individual spatial situation [56].

As the synthesis of the emotional and intellectual approaches to environment is an important prerequisite for architectural design, it was believed that precise sociological and spatial investigation of geographical and cultural ambiences can provide answers to the many questions and problems related to interaction between residents and the environment.

During the period of postmodernism, sociological research was continuously highlighted as a prior condition for designing a quality ambience. For example, the architects of the residential settlement "Julino brdo" (Figure 7), Lojanica, Cagić and Jovanović, while criticizing modernist urban planning and zoning, underline the importance of ambience in improving dwelling conditions and above all its social and psychological aspects: "Ambience includes all the formal elements, but also those human, social, that are difficult to predict" [57]. It is precisely this feature of ambience that asserts its significance and role in achieving cultural sensitivity, i.e., the ability to respond to the unpredictability of human behavior and local context. According to the architects, in opposition to the postmodern ambience characterized by contrast, authenticity, a sensitive relationship with the environment, the modernist ambience of New Belgrade's settlements is described as "dozens of perforated blocks, meanders, and poor prison yards with an inescapable taste of the ghetto" [57]. 


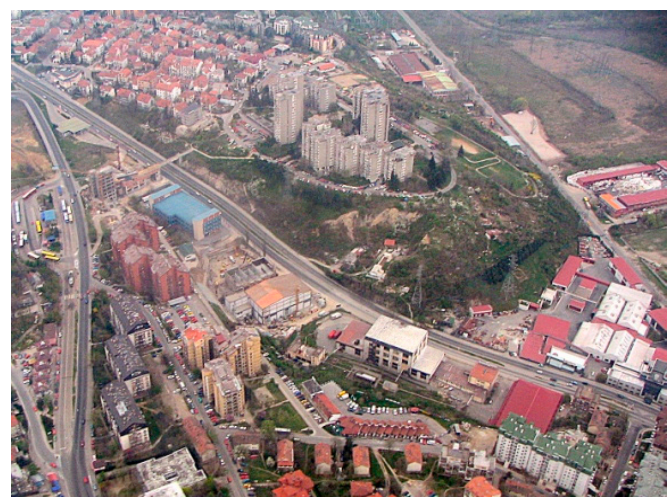

(a)

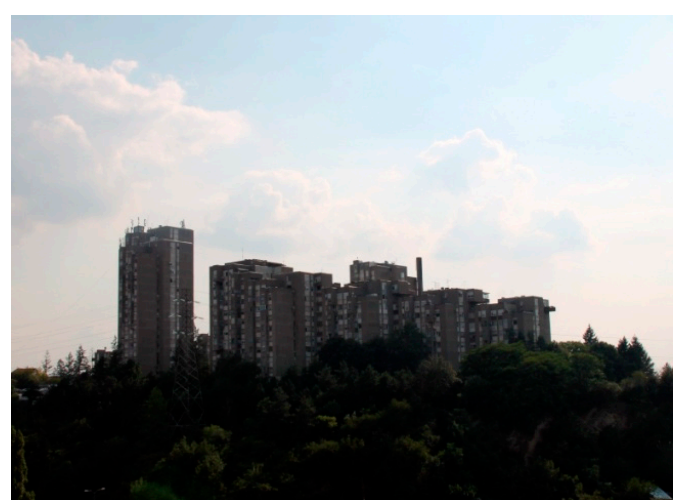

(b)

Figure 7. Residential settlement "Julino brdo". (a) Aerial view [58]; and (b) relationship of the settlement with geographical ambience () Verica Krstić.

Analysis shows that, in architectural terms, one of the fundamental topics of the postmodern period, beside the modernist concern for the ecological character of open and closed residential spaces, was the quality of human experience of nature. Together with its multiple roles as defense against noise, air pollution and excessive insolation, the positive medical, social and psychological effects of nature on residents were emphasized [59]. This is very important with regard to the impact of the experience of nature in residential areas on the identification of residents with the settlement, their sense of belonging and their general health. It should be emphasized that these aspects are also crucial for achieving cultural sensitivity in residential environments. For example some architects believe that greenery and its design concept not only affect the people's awareness of culture and representation, but also act as a regulator of the human-environment relationship. Furthermore, our analysis shows that the architects of residential settlements believed the influence between man and the environment was reciprocal. Such views are in line with the contemporary understanding of mentioned relations in sustainable development theories. Awareness of the importance of greenery in residential areas, however, was not accompanied by proper application of such knowledge in the design and construction of settlements. A design practice that left the realization of green spaces to "irresponsible factors" was strongly criticized, as it not only neglected the relationship of greenery and the object, but also deprived it of its elementary functions, highlighting especially the scarcity of elements of aesthetic and decorative value [60]. Such an attitude towards the ecological and cultural characteristics of context significantly affected the reduction of ambience qualities of the mentioned settlements. Regardless of the postmodernist awareness of the importance of ambience and the tendency to promote it in the newly designed residential settlements, open spaces were also criticized by residents in this period [61].

Despite such problems, however, the analyzed aspects of ambience and the relationship towards the environment were evidently improved in the postmodernist era. The specific urbanistic scheme of Block 19a in New Belgrade obviously differs from the usual New Belgrade's modernist block. According to the architects, reasons behind such a decision were primarily related to the characteristics of the local ecological context. From the point of view of ecology, in order to ensure the optimal positioning of objects for the purpose of protection from noise and air pollution that are highly expressed at this location, the architects used the principle of positioning "residential objects in the middle of the space as the ecologically friendliest zone" [62]. The architects thus opted not to employ the organizational model of residential blocks previously used in New Belgrade, which advised to position residential objects along boulevards on the block's edges and to leave green "gaps" [62]. The relationship between open green spaces and objects was given special treatment in the example of this residential settlement. Although the ideology of unification and prefabrication was still present in the block's architecture, the way in which space was treated enabled the formation of diverse ambiences within the block (Figure 8). 


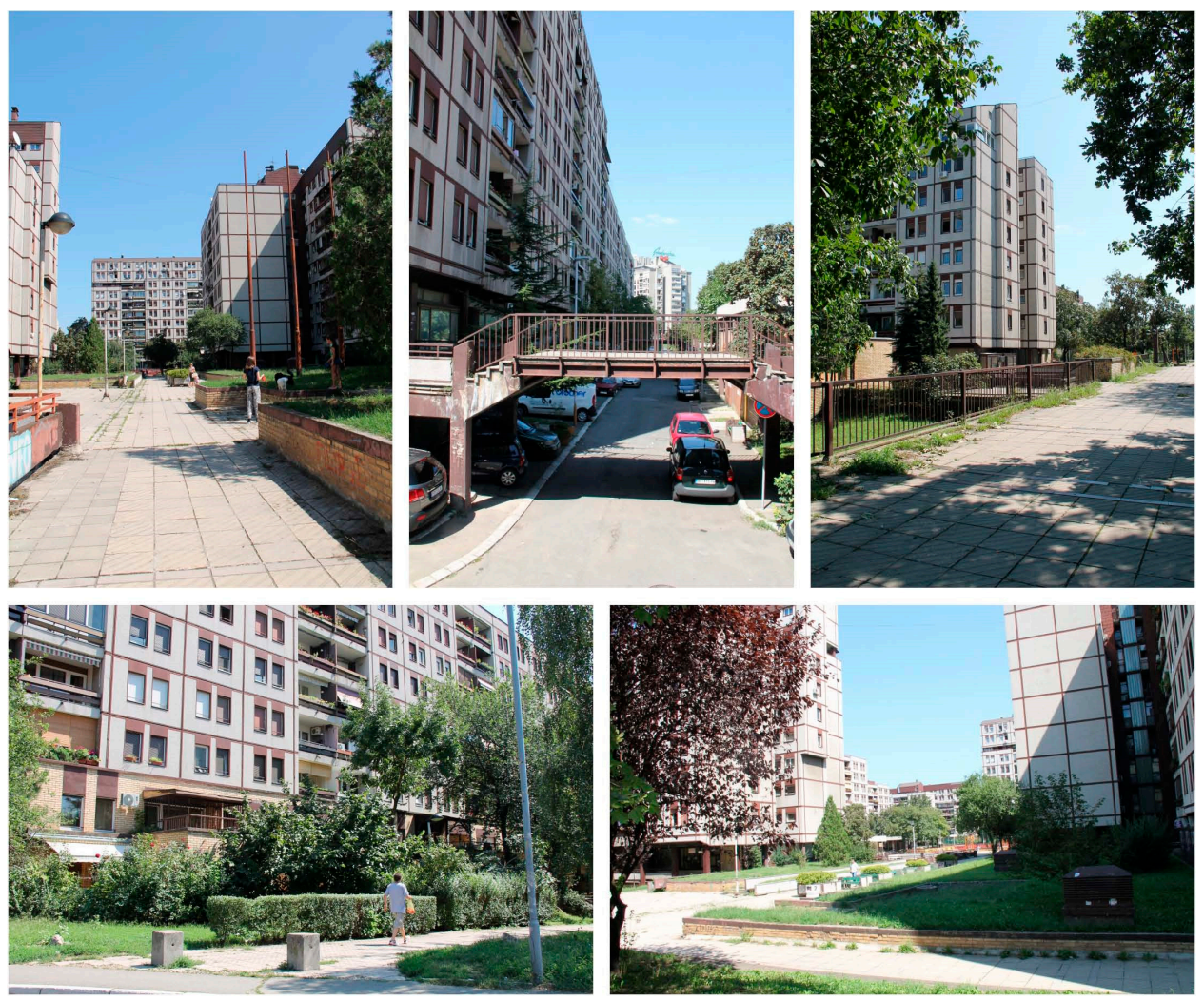

Figure 8. Ambiences of the residential settlement Block 19a @ Verica Krstić.

The photographs provided (Figure 8) also document the identification and appropriation of open spaces by the residents, particularly evident in ground floors where the objects come into contact with greenery and where green zones have been fenced off and joined with residential units. These gardens and allotments, whether spontaneously raised (Block 19a) or designed and planned ("Cerak vinogradi" settlement, Figure 9), serve to confirm the hypothesis that identification with the settlement is of crucial value. As already stated, the population of New Belgrade's residential units consisted largely of migrants from rural areas. In this sense, cultural values of the immigrants greatly influenced the way they used their environment. Therefore, as a result of the need for direct contact with nature, spontaneously generated allotments were made in some New Belgrade's residential settlements as a form of illegal action. These gardens speak of the need and importance of identifying with the natural environment, of belonging to a particular space, in order to plant flowers or to practice more advanced forms of gardening. Such behavior by residents points to the significance of ambience and local urban culture as a form of differentiation, a specificity, which greatly influences the results of the process of population's identification with the settlement. Accordingly, improved relations between the natural and built elements of an environment, as well as improved resident contact with nature were emphasized as future priorities in urbanism and architecture [63].

In relation to the topic of ambience and its authenticity, realization of the residential settlement "Cerak vinogradi" (Figure 9) should certainly be highlighted. According to the architects, in designing this settlement, special notice was given to creating ambiences in the urbanistic context of the settlement: "The desire to form ambiences-spaces between houses, where people move about and spend their time, with which they identify, is superior to the other design activities" [56]. The attitude of the architects towards materialization and the visual identity of objects in the settlement are particularly interesting. They believed that houses carry the function of ambience and that they "materialize" it, but that ambiences have an advantage over houses. Advantage of ambiences over houses was advocated due to a belief that the design of good, beautiful and different houses is no guarantee for 
good ambience and that, on the other hand, we know many examples of successful city ambiences realized with humble architectural edifices [56].
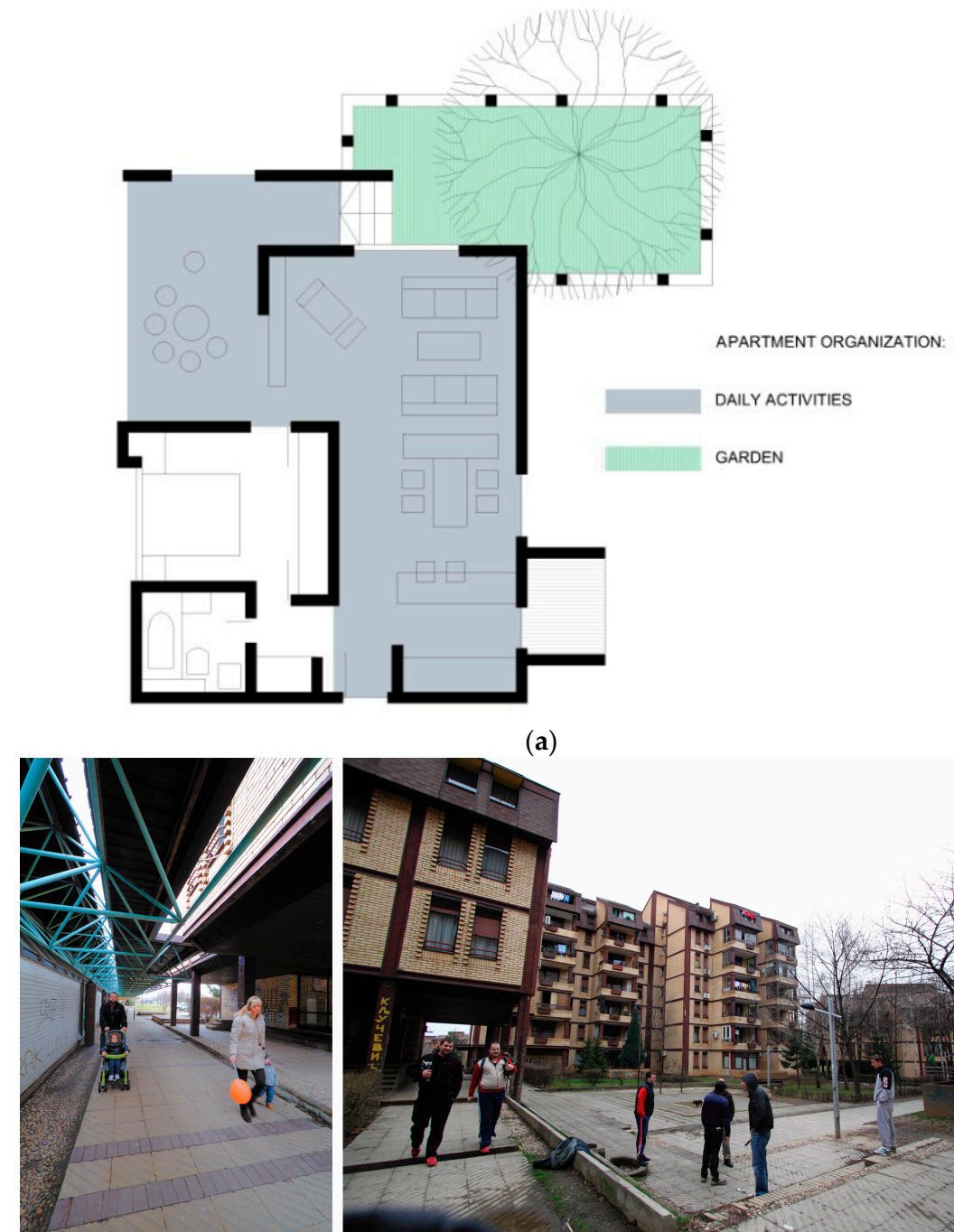

(a)
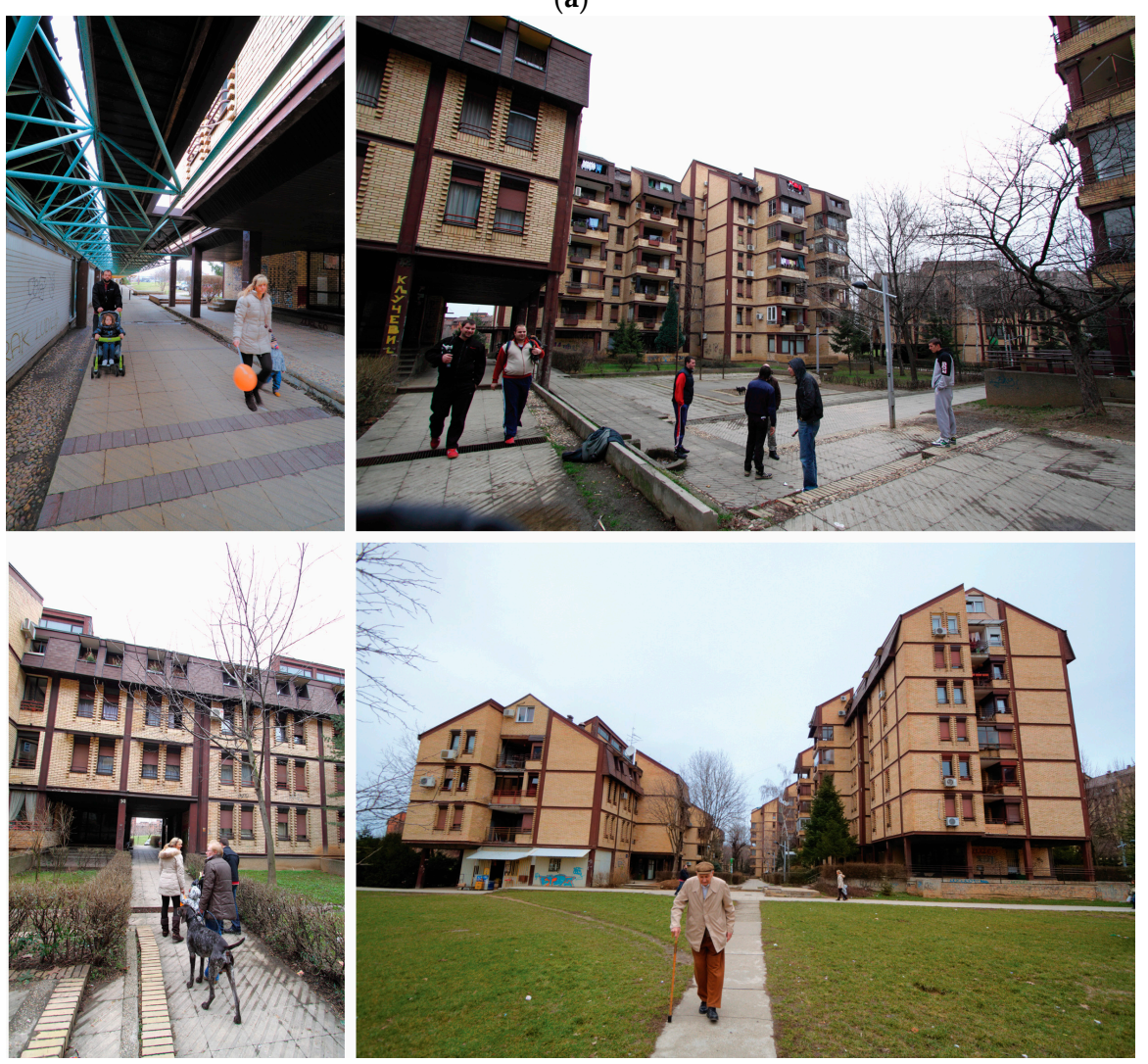

(b)

Figure 9. Settlement "Cerak vinogradi”. (a) Ground floor gardens; (b) ambiences @ Andrija Budjevac.

As the architects stress, due to the propositions of programs, terms of construction technology and deadlines for realization, in the residential settlement "Cerak vinogradi" they could not attempt to achieve authenticity of ambience using houses that would form a street front and make it authentic and 
different, like on a traditional street. Consequently, instead of houses "building" the street by way of different architectural interpretations, the architects designed different ambiences in which the houses are located: "[ ... ] the element of identification is the space of the house and the fact that it belongs to a characteristic ambience ('my house is located on the elbow of the street' or 'on a rectangular square' or 'close to the center of the Southern Neighborhood' [ ... ]" [56].

This clearly makes evident the significance of authentic ambiences in allowing the resident to identify with a settlement. In addition, the authenticity of ambience has a direct effect on the resident's dynamic experience of an environment. The issue of dimensions, analyzed above in the context of traditional values, is directly linked with the dynamics and authenticity of an ambience.

\section{Discussion}

In Yugoslavia, awareness of the necessity of introducing environmental aspects into architecture developed as an echo of the current global issues of environmental pollution and oil crises of the second half of the 20th century. As part of different initiatives and movements created in Yugoslavia during the 1960s, 1970s and 1980s, architecture became an important element in the general critique of a non-ecological and exploitative relationship with the environment.

From the end of the 1960s to the late 1980s, Yugoslav society was undergoing a complex process of transformation. As Ignjanović states, the general attitude toward mainstream ideology, its system of values, as well as the people's own reality with specific views on tradition and visions of national future, was gradually redefined in this period [50]. In architecture, these social changes were accompanied by a shift in architectural styles. Modernist principles were replaced by ideas of postmodernism which better suited the transformed social ideology. The consequence of the described changes was an obvious difference in the architectural approach to design and construction of residential settlements, and in the priorities related to environmental aspects. Unlike the priorities of postmodernism that coincided with the global development of the idea of sustainable growth (at the beginning of the 1970s), environmental topics were not high on the list of priorities of modernists in Yugoslavia.

Although we may detect signs of budding awareness about the importance of environmental aspects, modernists were primarily concerned with the universal hygienic and ecological principles in designing settlements under the rules of modernism, almost completely neglecting the local ecological and cultural characteristics of the context. In modernism, in accordance with the principles of socialist ideology, the priority was to build as many units as possible, which inevitably led to unification, universality and the lowering of standards in residential construction. In addition, socialist ideology inspired a breach with tradition and traditional values with the aim of representing new social values in the creation of a new socialist way of life and the efficiency of construction. This is especially related to the belief that architects, urbanists and planners had the ability to change the environment and also the society through their projects [38]. The fact that the architecture of socialist Yugoslavia became a tool in forming the identity of a new social working class was based on this assumption. As a consequence of this approach, the idea was to proclaim the new society's values praising virtues such as equality, technological progress, social justice, post-war reconstruction of the country, etc. Residential ambiences thus became much poorer and the residential areas insensitive to the ecological and cultural characteristics of the context. Contrary, in the architectural design and the theoretical works of the postmodern period, sustainability issues were recognized in the attitude towards the ecological and social contexts, ambience, tradition, resident needs, natural elements and the initiative to investigate and promote the relations and interactions between residents and the environment [22]. In the postmodern period, settlements did not primarily have political character or a role in the formation of the new society, and architects were thus allowed to draw attention to other topics and focus on more pressing environmental issues of living in settlements.

In addition, it is important to highlight that the models on which architects relied when designing differed greatly. For example, analyses show that under the influence of modernism such models were most often oversimplified, both with regard to humans and environment. Most importantly, 
as key theorists claim, the model of the relation between residents and the environment was not only oversimplified but to a large extent also wrong. The environment in general was considered a physical parameter of human behavior; however, from today's perspective, it is clear that the environment is much more complex, including also cultural and social components [10]. Besides, the physical, cultural and social contexts were firmly connected to form an open rather than a closed system [22]. The general view was that environment, especially its artificial architectural component, had a deterministic influence on many aspects of human life. This is a highly simplified and naive model of observing the environment-behavior interface, though today still often present in architectural thought. Regardless of such a simplified model of the ecological contexts of an object, however, we cannot disregard the fact that the idea and awareness of environmentally responsible architecture developed during the modernist era. In this period, in the architectural design of the time we may recognize a desire to provide a healthy habitat providing sun, fresh air and greenery. Although there is significant resemblance to the contemporary principles of sustainable design, residential settlements in Belgrade built under the influences of modernism have still been sharply criticized for their neglect of the characteristics of local context, climate, place, etc.

Unlike in the period of modernism in architecture, in the postmodern period, there was an awareness that the environment is in constant flux with anthropogenic influences. Underlining the conceptual shift from a unilateral and deterministic impact of environment on people to a more complex interactional concept and recognition that the relationship between humans and environment is not as direct and causal as the deterministic paradigm had proposed, the role of environmental theories in the architecture of this period was to highlight the complexity of resident needs and the general complexity of the environment [22]. Environmental aspects and the issues of tradition and ambience gained a major role in the design process due to this assumption. In addition, the design process acknowledged the importance and need for the residents to identify with their settlement, to belong to a particular space, expressed by a desire to plant flowers or through other activities. Such behavior by the residents points to the importance of local urban culture as a form of differentiation, a specificity greatly affecting the results of the residents' identification with the settlement. All these aspects confirm an awareness of the significance of ecological and cultural sensitivity in designing quality residential ambiences. Accordingly, architects realized that in order to achieve sustainable surroundings, it was important to include the qualitative and experiential aspects of the environment alongside the technological aspects prioritized in modernism. Criticism of the modern period involving this issue focused on the problem of the emotional component of the experience of space lagging behind the rational one: "Many philosophers have noticed a typical trait of the modern era: the lagging of the experiential component of space behind those of rational cognition, which can best be seen in that, today already insurmountable gap and rift that exists between the scientific world view and man's perceptions of the world" [64]. Experience of space thus evidently became an increasingly important topic in this period.

Research results have revealed that, due to the specific historical conditions of socialism, complex hybrid forms of approach to environmental issues evolved in the architectural practice of residential settlements. This specific trait was first a consequence of the size of these large-scaled settlements. Under these conditions, implying unification and standardization and developing in a context completely different from the traditional residential context of central urban areas of Belgrade, new models in the design process were required. Regardless of harsh criticism and the negative aspects of the settlements built under the influence of modernism, it is important to point out that awareness about the qualities and positive characteristics of modernist settlements was very much present in postmodernism. Analysis shows that architects, along with new priorities and an improved relationship with the environment in the postmodern period also strived to preserve and promote the recognized qualities of modernist residential settlements. In the context of socialist ideology and the large scale of the residential settlements, this was certainly a challenge that significantly affected the specificity of applied solutions in the architecture of these settlements. An excellent example is the settlement "Cerak vinogradi". The architects of this settlement, in an attempt to design authentic 
ambience, were faced with the fact that they were unable to influence the authenticity and diversity of facades forming the open-space ambiences in the settlement, due to the large size of the mentioned settlement, the design program imposed by the state and the necessity to build using prefabrication. Aware that it is precisely the facades and the various forms of objects in a traditional city that provide identity and give specific traits to the ambiences of open spaces, they were forced to seek out other solutions that suited the social and technological conditions under which the settlement was to be realized. The design of open-space ambiences and emphasis on their diversity and authenticity and a specific relationship with the ecological and cultural contexts significantly affected the sensitivity and sustainability of this settlement. In addition, the specific way of applying traditional urban forms in the architectural design of the prefabricated facade in New Belgrade's Block 19a became a colorful and familiar trait of the ambience of the created settlement.

Research of residential settlements from the analyzed period clearly demonstrates the necessity of improving the architectural practice and the awareness of the importance of issues of tradition and ambience in architecture, while also revealing the problems and the lack of adequate implementation of these issues in the architecture of this specified period. In its final consequences, the results of research confirm the significance of local cultural-ecological contexts in the architectural design of residential settlements and its potential to endure the often unpredictable characteristics of human behavior and local context. The examples given show that disregard for these aspects was sharply criticized first of all by the residents, but also by the expert community, i.e., that their neglect led to a dissatisfying degree of ecological and cultural sensitivity. With the goal of promoting and improving the ecological and cultural sensitivity of architectural practice, issues were raised of the operationalization of existing environmental knowledge in architectural practice and overcoming the gap between the positions of architecture as art and environmental practice. The basic problem in overcoming this gap was that most architects and institutions in charge of educating architects did not recognize it as a problem, and its recognition is crucial for promoting the application of sustainable theories in architecture, urbanism and landscape architecture $[65,66]$. It is important to overcome this difference in order to promote sustainability, as it contributes to a simultaneous focus on the aesthetic and environmental aspects of residential surroundings, focus on the perception of the object and the environmental perception, on the visual and environmental qualities of objects, but also on the desire to provide residents with adequate living conditions by promoting the human habitat as a whole. Along these lines, sustaining environmental aspects through the residential environment benefits the overall quality of life as it helps raise ecological and cultural sensitivity and awareness, helping to preserve the diversity of cultural heritage that enriches our environments.

Acknowledgments: This paper was written as a part of the projects "Studying climate change and its influence on the environment: impacts, adaptation and mitigation" (43007) and "Research and systematization of housing development in Serbia in the context of globalization and European integrations for the purpose of improving housing quality and standards" (TR36034), financed by the Ministry of Education and Science of the Republic of Serbia for the period 2011-2016.

Author Contributions: In the process of designing and performing the research, Vladan Djokic was the academic advisor, whose concrete suggestions regarding subject and methodology led to the finalization and presentation of the research results. Jelena Ristić Trajković designed and performed the research, analyzed the data, and wrote the initial draft paper. Verica Krstic contributed substantially to improving and editing the paper. In the end, all three authors have equally contributed to writing the final version of the paper. All authors have read and approved the final manuscript.

Conflicts of Interest: The authors declare no conflict of interest.

\section{References}

1. Blagojević, L. Strategije Modernizma u Planiranju i Projektovanju Urbane Strukture i Arhitekrure Novog Beograda: Period Konceptualne Faze od 1922. do 1962. Godine. Ph.D. Thesis, University of Belgrade, Belgrade, Serbia, 2004. 
2. Blagojević, L.; Ćorović, D. Klimatske promene i estetika savremene arhitekture. In Uticaj Klimatskih Promena na Planiranje i Projektovanje; Djokić, V., Lazović, Z., Eds.; Arhitektonski Fakultet: Belgrade, Serbia, 2011; pp. 19-33.

3. Anker, P. From Bauhaus to Ecohouse: A History of Ecological Design; Louisiana State University Press: Baton Rouge, LA, USA, 2010.

4. Corbusier, L. Atinska Povelja; Klub Mladih Arhitekata: Belgrade, Serbia, 1972.

5. Ristić Trajković, J.; Stojiljković, D.; Ćirić, D. Transformation of modern urban space of New Belgrade in the conditions of the post-socialist transition and sustainable development. In Procedings of the 12th International Docomomo Conference, Espoo, Finland, 7-10 August 2012; pp. 381-388.

6. Van der Ryn, S.; Cowan, S. Ecological Design; Island Press: Washington, DC, USA, 2007.

7. Farmer, J. Green Shift: Towards a Green Sensibility in Architecture; Butterworth Architecture: Oxford, UK, 1996.

8. Hagan, S. Taking Shape. A New Contract between Architecture and Nature; Architectural Press: Oxford, UK, 2001.

9. Spiegl, A. A Panorama of the Artifactual. In Your Black Horizon Art Pavilion. Olafur Eliasson and David Adjaye; Ebersberger, E., Zyman, D., Eds.; D.A.P.: Köln, Germany; New York, NY, USA, 2007; pp. 85-141.

10. Guy, S.; Farmer, G. Reinterpreting Sustainable Architecture: The Place of Technology. J. Archit. Educ. 2001, 54, 140-148. [CrossRef]

11. Lefebvre, H. The Production of Space; Blackwell: Oxford, UK; Cambridge, MA, USA, 1991.

12. Nikezić, A.; Marković, D. Place-Based Education in the Architectural Design Studio: Agrarian Landscape as a Resource for Sustainable Urban Lifestyle. Sustainability 2015, 7, 9711-9733. [CrossRef]

13. Hawkes, D. The Environmental Imagination: Technics and Poetics of the Architectural Environment; Routledge: London, UK; New York, NY, USA, 2008.

14. Soini, K.; Dessein, J. Culture-Sustainability Relation: Towards a Conceptual Framework. Sustainability 2016, 8, 167. [CrossRef]

15. Borch, C. Architectural Atmospheres: On the Experience and Politics of Architecture; Birkhäuser: Basel, Switzerland, 2014.

16. Moravánszky, A. My Blue Heaven: The Architecture of Atmospheres. AA Files 2010, 61, 18-22.

17. Pallasmaa, J.; Holl, S.; Pérez Gómez, A. Questions of Perception: Phenomenology of Architecture; William Stout Publishers: San Francisco, CA, USA, 2006.

18. Pallasmaa, J. Space, Place, and Atmosphere: Peripheral Perception in Existential Experience. In Architectural Atmospheres, On the Experience and Politics of Architecture; Borch, C., Ed.; Birkhäuser: Basel, Switzerland, 2014; pp. $18-41$.

19. Groat, L.N.; Wang, D. Architectural Research Methods; J. Wiley: New York, NY, USA, 2002.

20. Ristić Trajković, J.; Stojiljković, D.; Međo, V. Influence of the Socialist Ideology on the Conception of Multi-Family Housing: New Urban Landscape and the Typological Models of Housing Units. Facta Univ. Ser. Archit. Civil Eng. 2015, 13, 167-179. [CrossRef]

21. Jovanović-Nenadović, L. Koncepcija Projektovanja Stambenih Jedinica u Novom Beogradu-Analiza Konkursnih Rešenja u Periodu 1966-1975. Godine. Master's Thesis, University of Belgrade, Belgrade, Serbia, 2011.

22. Ristić Trajković, J. Architecture and Nature: The Application of Environment-Behavior Theories in Architectural Design. Ph.D. Thesis, University of Belgrade, Belgrade, Serbia, 2015.

23. Marković, D.Ž. Socijalna Ekologija; Zavod za Udžbenike i Nastavna Sredstva: Belgrade, Serbia, 1986.

24. United Nations. Report of the World Commission on Environment and Development. In General Assembly Resolution 42/187; United Nations: New York, NY, USA, 1987.

25. Čiček, J. Samoupravne intresne zajednice za zaštitu čovjekove okoline. Čovjek i Prostor 1975, 269, 21-23.

26. Keller, G. Budućnost kakvu zavređujemo. Čovjek i Prostor 1973, 241, 19-22.

27. Kiš, D. Ekologija i prostorno planiranje. Čovjek i Prostor 1973, 238, 16-18.

28. Kiš, D. Čovjekova sredina u vrijeme brze urbanizacije u Jugoslaviji. Čovjek i Prostor 1971, 225, 32.

29. Keller, G. Socijalizam i ekologija. Čovjek i Prostor 1973, 243, 24.

30. M., F. Marksistički pristup ekologiji. Čovjek i Prostor 1978, 309, 4.

31. Meštrović, M. Uporaba okoline. Čovjek i Prostor 1979, 313, 19.

32. Petrinović, Z. Svjetski dan urbanizma i čovjekove sredine. Čovjek i Prostor 1973, 242, 27.

33. Stojanović, B. Odnos prema prirodi. In 40 Godina Građevinarstva Socijalističke Republike Srbije; Jarić, M., Ed.; Izgradnja: Belgrade, Serbia, 1987; pp. 73-74. 
34. Karnovšek Ljuckanov, N. U susret sunčanoj energiji. Čovjek i Prostor 1978, 300, 13.

35. Venturini, D. Komercijalna upotreba sunčane energije. Čovjek i Prostor 1978, 300, 13.

36. Ragon, M. Urbanizam i sunčana energija. Čovjek i Prostor 1974, 258, $20-21$.

37. Lukić, M. Emocionalni i psihološki aspekti stanovanja u novim naseljima. Urban. Beogr. 1979, 53-54, $33-36$.

38. Groat, L.N.; Despres, C. The Significance of Architectural Theory for Environmental Design Research. In Advances in Environment, Behavior, and Design; Zube, E.H., Moore, G.T., Eds.; Plenum Press: New York, NY, USA; London, UK, 1991; Volume 3.

39. Banham, R. The Architecture of the Well-tempered Environment; Architectural Press: London, UK, 1984.

40. Corbusier, L. The City of Tomorrow; Architectural Press: London, UK, 1987.

41. Ribnikar, V. Problem stanbenih zgrada. Arhitektura 1950, 11-12, 16-19.

42. Jencks, C. The Language of Post-Modern Architecture, 6th ed.; Rizzoli: New York, NY, USA, 1991.

43. Appleyard, D. The Environment as a Social Symbol: Within a Theory of Environmental Action and Perception. J. Am. Plan. Assoc. 1979, 45, 143-153. [CrossRef]

44. Harvey, D. The Condition of Postmodernity; Blackwell Publishing: Oxford, UK, 1990.

45. Savetovanje, B. Budućnost stambenih naselja. Beograd 26. 27. i 28. maj 1977. Stenografske beleške sa plenarne sednice 28. maj 1977. godine. In Komunikacije '77; Centar za Planiranje Urbanog Razvoja: Belgrade, Serbia, 1977.

46. Radna Grupa, D. Kako početi život u novom naselju-Problemi identifikacije i socijalne integracije. In Budućnost Stambenih Naselja. Planiranje, Programiranje, Urbanističko Projektovanje, Realizacija, Korišćenje. Komunikacije '77; Centar za Planiranje Urbanog Razvoja: Belgrade, Serbia, 1977.

47. Perović, M. Iskustva Prošlosti; Plato: Belgrade, Serbia, 2000.

48. Google Maps. Available online: https://www.google.rs/maps/search/\%D0\%91\%D0\%BB $\%$ D0\%BE\% D0\%BA+1+2,+\%D0\%91\%D0\%B5\%D0\%BE\%D0\%B3\%D1\%80\%D0\%B0\%D0\%B4/@44.8255724,20.4049091, $1313 \mathrm{~m} /$ data $=! 3 \mathrm{~m} 1 ! 1 \mathrm{e} 3 \mathrm{hl}=\mathrm{sr}$ (accessed on 10 July 2016).

49. Google Maps. Available online: https://www.google.rs/maps/place/\%D0\%91\%D0\%BB $\%$ D0\%BE\% D0\%BA+1,+\%D0\%91\%D0\%B5\%D0\%BE\%D0\%B3\%D1\%80\%D0\%B0\%D0\%B4/@44.7814675,20.3848966, $16234 \mathrm{~m} /$ data $=$ !3m1!1e3!4m5!3m4!1s0x475a6579ddf0dedd:0xebad449c9fc960e8!8m2!3d44.8230969!4d20. 4102172?hl=sr (accessed on 10 July 2016).

50. Ignjatović, A. Poricanje i obnova: Arhitektura postmodernizma 1980-1991. In Istorija Umetnosti u Srbiji XX vek; Šuvaković, M., Ed.; Orion Art: Belgrade, Serbia, 2010; pp. 663-670.

51. Böhme, G. Urban Atmospheres: Charting New Directions for Architecture and Urban Planning. In Architectural Atmospheres: On the Experience and Politics of Architecture; Borch, C., Ed.; Birkhäuser: Basel, Switzerland, 2014; pp. 42-59.

52. Dakić, S.; Kritovac, F. Okolina Je Proces. Teoretske Mogućnosti Jedne Nove Prakse. Arhitektura 1973, 146-147. Available online: http://www.uha.hr/hr/publikacije/casopisi/arhitektura/ARHITEKTURA146-147 no16131/Okolina-je-proces-teoretske-mogucnosti-jedne-nove-prakse no16140/ (accessed on 8 September 2016).

53. Pasinović, A. Integritet prostornog jedinstva. Arhitektura 1969, 104, 5-7.

54. Dobrović, N. Osvrt na temu ambijent. Arhitektura 1965, 90, 7.

55. Google Maps. Available online: https://www.google.rs/maps/place/\%D0\%91\%D0\%BB $\% \mathrm{DD} \% \mathrm{BE} \%$ D0\%BA+21,+\%D0\%91\%D0\%B5\%D0\%BE\%D0\%B3\%D1\%80\%D0\%B0\%D0\%B4/@44.8153885,20.4266243, $1261 \mathrm{~m} /$ data $=! 3 \mathrm{~m} 1 ! 1 \mathrm{e} 3$ !4m5!3m4!1s0x475a655e88abab17:0xf9dfbd3e64bd807e!8m2!3d44.8145051!4d20. 4303868 ?hl=sr (accessed on 10 July 2016).

56. Marušić, M.; Marušić, D. Cerak 1 i Cerak 2. Cerak u 20 slika. In 40 Godina Građevinarstva Socijalističke Republike Srbije; Jarić, M., Ed.; Izgradnja: Belgrade, Serbia, 1987; pp. 127-136.

57. Manević, Z. Lojanica, Jovanović, Cagić: Julino brdo u Beogradu. Čovjek i Prostor 1971, 217, 10-12.

58. Wikipedia. Julino Brdo. Available online: https://sr.wikipedia.org/wiki/\%D0\%88\%D1\%83\%D0\%BB\%D0\% B8\%D0\%BD\%D0\%BE_\%D0\%B1\%D1\%80\%D0\%B4\%D0\%BE\#/media/File:Julino_brdo_from_airplane.jpg (accessed on 10 July 2016).

59. Mišić, R. Novi Beograd sa gledišta urbane higijene. Novi Beograd-Novi grad u Gradu. Urban. Beogr. 1973, 25, 4-7.

60. Lukić, M. Zelenilo kao urbanistička komponenta. Čovjek i Prostor 1965, 149-150, 5.

61. Lazić, S. Kako stanovnici doživljavaju otvorene prostore stambenih naselja. Arhit. Urban. 1976, 74-77, 94-97. 
62. Lojanica, M. Blok 19a u Novom Beogradu. In 40 Godina Građevinarstva Socijalističke Republike Srbije; Jarić, M., Ed.; Časopis Izgradnja: Beograd, Serbia, 1987; pp. 123-126.

63. Mutnjaković, A. Grad našeg radosnog sutra. Arhit. Urban. 1964, 25, $22-23$.

64. Meštrović, M. U procijepu između umjetnosti i nauke. Arhit. Urban. 1964, 25, 19-20.

65. Dayaratne, R. Environment-Behavior Research and the Practice of Architecture: Paradigms and Paradoxes. Built Environ. Sri Lanka 2002, 3, 38-45. [CrossRef]

66. Lang, J. Design Theory from an Environment and Behavior Perspective. In Advances in Environment, Behavior, and Design; Zube, E.H., Moore, G.T., Eds.; Plenum Press: New York, NY, USA; London, UK, 1991; Volume 3, pp. 53-102.

(C) 2016 by the authors; licensee MDPI, Basel, Switzerland. This article is an open access article distributed under the terms and conditions of the Creative Commons Attribution (CC-BY) license (http://creativecommons.org/licenses/by/4.0/). 